\title{
The effects of oil pollution on the marine environment in the Gulf of Guinea - the Bonga Oil Field example
}

\begin{abstract}
:
Fish makes a significant contribution to the food security of millions of people in the Gulf of Guinea, accounting for up to 80 per cent of the animal protein, and sometimes is the only source of thereof, consumed in coastal communities across the region, including those in the Niger Delta area of Nigeria. However, such contribution is increasingly undermined by unsustainable practices that are harmful to the marine environment such as pollution, illegal, unreported and unregulated (IUU) fishing, and by climate change. This paper focuses on the role that pollution from oil spillages plays in damaging the marine environment, thereby exacerbating food insecurity in the region. Using the Bonga Oil Field spillage example, the paper exposes, from a policy perspective, the manner in which the shortcomings of existing environmental regulations and their implementation in Nigeria weaken efforts for a sustainable marine environment and, by extension, threatens the food security of coastal communities.
\end{abstract}

Keywords: Property Law; Development; Transnational Food Security; Environ mental Regulations; Niger Delta

\author{
Author: \\ Ifesinachi Okafor-Yarwood \\ $\mathrm{PhD}$ candidate, Leadership, Security and Development \\ African Leadership Centre, \\ King's College London. \\ ifesinachi.okafor@kcl.ac.uk
}

All websites accessed: $16^{\text {th }}$ December 2018 .

\section{Acknowledgement:}

The author would like to thank Mr. Peter Sharpe and Mr. Anthony Davenport for copyediting the initial drafts of this paper. The author also wants to thank her PhD supervisors, Dr Eka Ikpe and Prof. Funmi Olonisakin for their continued guidance. A special thank you also to Rev. Ayadi and fisher folks in Bonny Local Government area in Rivers State, Nigeria, for contributing to the data for this paper, and to the organisers of the Transnational Food Law Symposium for providing the platform for the subject to be discussed. Above all, the author is thankful to Almighty God. 


\section{Introduction}

Fisheries contribute to enhancing food security either by acting directly as a source of essential nutrients or as a source of income for coastal communities who mostly depend on the resource for subsistence. ${ }^{1}$ They serve as a source, and sometimes the only source, of animal protein for many living in coastal communities in West and Central Africa - which make up the Gulf of Guinea defined here, in the broad sense, as the coastal states stretching from Senegal to Angola. ${ }^{2}$ Fisheries also play a significant role in food security by augmenting food supply and consumption in times of scarcity and by generating income for the purchase of food. ${ }^{3}$ For 40 per cent of the West African population who live in the coastal areas, the fisheries sector plays a significant role in their food and economic security, employing an estimated nine million people in the region alone. ${ }^{4}$ However, these contributions are existentially threatened by the impact of climate change, pollution and unsustainable fishing practices that undermine the marine environment. ${ }^{5}$

The sustainability of the marine environment and the resources that lie beneath it have been undermined by the global rise in sea levels, which has resulted in a significant increase in the ocean's uptake of $\mathrm{CO}_{2}$; the release of toxic wastes into the ocean; and, further to this, unsustainable practices such as illegal, unreported and unregulated (IUU) fishing. ${ }^{6}$ These issues make the potential for food insecurity a high risk for coastal communities across the Gulf of Guinea. Specifically, climate change has been implicated as undermining the marine environment and leading to a depletion in fisheries resources. ${ }^{7}$ According to the World Bank, by 2050 climate change will contribute to the reduction of

\footnotetext{
1 Serge M. Garcia, "World Inventory of Fisheries. Contribution of Fisheries to Food Security. Issues Fact Sheets." (Rome, 2005).

${ }^{2}$ See Ifesinachi Okafor-Yarwood, “The Guinea-Bissau-Senegal Maritime Boundary Dispute," Marine Policy 61 (2015): 284-90, https://doi.org/10.1016/j.marpol.2015.08.008, p.285; Ifesinachi Okafor-Yarwood, "Illegal, Unreported and Unregulated Fishing, and the Complexities of the Sustainable Development Goals (SDGs) for Countries in the Gulf of Guinea," Marine Policy 99 (2019): 414-22, https://doi.org/10.1016/j.marpol.2017.09.016.

${ }^{3}$ Serge M S.M Garcia and Andrew A.A Rosenberg, "Food Security and Marine Capture Fisheries:

Characteristics, Trends, Drivers and Future Perspectives," Philosophical Transactions of the Royal Society 365 , no. 1554 (September 27, 2010): 2869-80.

${ }^{4}$ Okafor-Yarwood, "Illegal, Unreported and Unregulated Fishing, and the Complexities of the Sustainable Development Goals (SDGs) for Countries in the Gulf of Guinea.", p.414.

${ }^{5}$ R.E Katikiro and E.D Macusi, "Impacts of Climate Change on West African Fisheries and Its Implications on Food Production," Journal of Environmental Science and Management 15, no. 2 (2012): 83-95; UNEP, "Environmental Assessment of Ogoniland" (Kenya, 2011), https://doi.org/10.3370/lca.2.73; Lawrence Etim, Dyhia Belhabib, and Daniel Pauly, "An Overview of the Nigerian Marine Fisheries and a Re-Evaluation of Its Catch Data for the Years 1950 to 2010," Fisheries Centre, University of British Columbia (Vancouver, 2015). ${ }^{6}$ I. Okafor-Yarwood, "Nigeria's Depleting Fish Stocks May Pose a Threat to Regional Security," The Conversation, 2018.

${ }^{7}$ VWY Lam et al., "Climate Change 2007: Impacts, Adaptation, Vulnerability. Contribution of Working Group II to the Fourth Assessment Report of the Intergovernmental Panel on Climate Change," in African Journal of Marine Science, vol. 34, 2012, 103-17; Edward H. Allison et al., "Vulnerability of National Economies to the Impacts of Climate Change on Fisheries," Fish and Fisheries 10, no. 2 (2009): 173-96, https://doi.org/10.1111/j.1467-2979.2008.00310.x.
} 
fisheries resources by up to 53 per cent in Nigeria, 56 per cent in the Ivory Coast and 60 per cent in Ghana. ${ }^{8}$ Also implicated in exacerbating the decline of marine resources is the impact of overfishing and criminal activities such as IUU fishing. ${ }^{9}$ So prevalent is the threat in the region that it amounts to an estimated 65 per cent of the legal catch, with Nigeria losing about \$29 million dollars per annum to illegal shrimping alone. ${ }^{10}$ Likewise, a great deal has been written about the impact of pollution by multinational oil companies and their role in damaging the marine environment in the Niger Delta area and by extension the rest of the Gulf of Guinea. ${ }^{11}$

It has been argued that the role of pollution in adversely affecting the ocean's resources is limited when compared to the impact of overfishing. Espousing this view, Till notes that the crisis in fish supply is largely due to unsustainable fishing — overfishing and IUU fishing — and not pollution. ${ }^{12}$ Whereas this paper recognises that overfishing and IUU fishing contribute to the decline in fisheries resources, it will focus on the role of pollution resulting from oil spillages by multinational oil companies operating in Nigeria. It does so by using the Bonga Oil Field spillage of 2011 as a case study. Emphasis on the Bonga Oil Field incident is crucial because little has been written regarding its effect on fisheries and the many people living in the affected communities who depend on fish for subsistence. The Niger Delta is usually described as ecologically diverse, its mangroves serving as a breeding ground for different species of fish in the Gulf of Guinea. ${ }^{13}$ This makes it a useful case study for understanding the long-term food security implications of the decline in fisheries resulting from pollution.

This paper employs qualitative research methods, such as primary interviews with the Coordinating Chairman of the Akwa-Ibom State, who is also the Acting Chairman of the Niger Delta Artisan Fishers

\footnotetext{
${ }^{8}$ Magda Lovei, "Climate Impacts on African Fisheries: The Imperative to Understand and Act," The World Bank Blog, 2017, http://blogs.worldbank.org/nasikiliza/climate-impacts-on-african-fisheries-the-imperative-tounderstand-and-act.

${ }^{9}$ Alkaly Doumbouya et al., "Assessing the Effectiveness of Monitoring Control and Surveillance of Illegal Fishing: The Case of West Africa," Frontiers in Marine Science 4, no. March (2017), https://doi.org/10.3389/fmars.2017.00050; Etim, Belhabib, and Daniel Pauly, "An Overview of the Nigerian Marine Fisheries and a Re-Evaluation of Its Catch Data for the Years 1950 to 2010."

${ }^{10}$ Okafor-Yarwood, "Illegal, Unreported and Unregulated Fishing, and the Complexities of the Sustainable Development Goals (SDGs) for Countries in the Gulf of Guinea."

${ }^{11}$ Kevin Nengia, "Pollution:Bonny Communities, Group Lament Illegal Bunkering," The Tide, December 2013, http://www.thetidenewsonline.com/2013/12/04/pollutionbonny-communities-group-lament-illegal-bunkering/; Patience Ivie Ihejirika, “'Niger Delta Oil Pollution Has Badly Affected Agriculture, Fishing," Leadership, June 8, 2016, http://leadership.ng/news/534056/niger-delta-oil-pollution-badly-affected-agriculture-fishing; Sunny Ofehe, "Environmental Pollution in the Niger Delta," accessed April 1, 2016,

http://www.ofehe.com/article3.htm; Emma Amaize, "Pollution Forces N-Delta Fishermen, Farmers to Abandon Occupation," Vanguard Nigeria, 2016, https://www.vanguardngr.com/2016/09/pollution-forces-n-deltafishermen-farmers-abandon-occupation/; A.A. Kafada, "Environmental Impacts of Oil Exploration and Exploitation in the Niger Delta of Nigeria," Global Journal of Science Frontier Research Environment \& Earth Svience 12, no. 3 (2012): 18-27.

${ }^{12}$ Geoffrey Till, Sea Power - a Guide for the Twenty Fisrt Century, 3rd ed. (London \& New York: Routledge, 2013), p.285.

${ }^{13}$ Olanike Kudirat Adeyemo, Oniovosa Eloho Ubiogoro, and Olufemi Bolarinwa, "Oil Exploitation, Fisheries Resources and Sustainable Livelihood in the Niger Delta, Nigeria," Nature \& Faune 24, no. 1 (2009): 56-61 p.59.
} 
Association of Nigeria (ARFAN) and the President of the Bonny Island Fishers Association, Bonny Local Government Area in Rivers State. In response to the empirical research, this paper argues that multinational oil companies continue to undermine the environment in which they operate not least as the existing regulations on petroleum exploration, and the obligations that they impose upon these multinationals in relation to the ecosystems under threat, are not robustly implemented. ${ }^{14}$ Section two sets the scene, using the Bonga Oil Field example to emphasise the food security implications of oil spillages on littoral communities in the Niger Delta region. This is followed by a review of selected environmental legislations and/or guidelines and the role of agencies in Nigeria such as the Federal Environmental Protection Agency (FEPA), the National Oil Spill Detection and Response Agency (NOSDRA), the National Environmental Standards and Regulation Enforcement Agency (NESREA) and Environmental Guidelines and Standards for the Petroleum Industry in Nigeria (EGASPIN). Although there are others, ${ }^{15}$ investigating the aforementioned provides sufficient concrete examples of the failures of existing regulations and agencies charged with the responsibility of ensuring a sustainable environment in Nigeria. The paper concludes with a brief discussion on the imperative of enacting amendments to further strengthen existing regulations and either establishing a new independent agency, or upgrading an existing one, to give it adequate powers to oversee a robust response to incidences of oil spillages.

\footnotetext{
${ }^{14}$ The interviews were conducted between December 2015 and June 2017 as part of the author's PhD thesis data collection.

${ }^{15}$ See Eghosa Osa Ekhator, "Environmental Protection in the Oil and Gas Industry in Nigeria: The Roles of Governmental Agencies," International Energy Law Review 5 (2013): 196-203; C. Cragg, J. Hurst-Croft, and I. Samiama, "Pollution Control in the Global Oil Industry in Relation to Reform in Nigeria" (Nigeria, 2011), http://www.stakeholderdemocracy.org/wp-content/uploads/2016/06/Environmental-Regulation-andPollution.pdf.
} 


\section{Pollution and food insecurity - The Bonga Oil Field Spillage example}

Fisheries contribute to the food security of communities in the Niger Delta, by serving as sources of income for many of the people living in the region. In some communities such as those in Bonny Local Government Area in Rivers State, around 70 per cent of the population depends on fish for their livelihood. ${ }^{16}$ For a lot of women living in the region, fish also provides an opportunity for them to earn a living as fisherwomen or fishmongers. ${ }^{17}$ However, the continued contribution of fish as a central food security resource is threatened by pollution in the form of oil spillages from the multinational oil companies operating in the area.

The food security implications of reduced catch have a devastating impact on the fisher folks who depend on fish for subsistence. According to Vreÿ one cause thereof is oil pollution which aggravates the threat to the marine environment, and thus undermines its contribution as a source of food. ${ }^{18}$ The Niger Delta region is one area that, over the years, has experienced severe pollution resulting from oil spillages. Specifically, since the exploitation of oil started in 1958, an estimated 13 million barrels of oil have been spilled in more than 10,000 incidents in the region. ${ }^{19}$ The multinational oil companies are of the view that most of these spillages are due to sabotage and/or vandalisation of pipelines. ${ }^{20}$ Whilst the role of sabotage in the many incidences of oil spillages in the Niger Delta cannot be denied, the reality, however, is that some of the pipelines used by the oil companies are dilapidated, with a considerable amount of the oil spillages due to the corrosion of aging facilities. ${ }^{21}$ The resulting effects of such pollution not only undermine the coastal environment, but they also increase human suffering especially for the communities affected. This is because those that rely on fisheries for subsistence are sometimes not able to engage in the trade for months as they are forced to wait for the clean-up exercises to be completed. The suffering is made worse because, in some cases, they are never compensated for their loss. ${ }^{22}$

\footnotetext{
${ }^{16}$ Dick Wittenberg, “Oil, Gas and Mining: The Bonny Island LNG Project: In Bonny It Never Becomes Night Anymore," ECA Watch, 2004, http://www.ecawatch.org/problems/oil_gas_mining/bonnyisland/BonnyIsland130704.html.

17 Tendai Marima, “There's an Invisible Cost to Nigeria’s Oil Spill Disasters," Quartz Media, 2016, https://qz.com/859201/theres-an-invisible-cost-to-nigerias-oil-spill-disasters/; Ibim Adaba Tonye and Amiye Francis, "Women and Post Harvest Fish Production in the Niger Delta Area," Journal of Agriculture and Veterinary Science 7, no. 3 (2014): 78-82.

${ }^{18}$ Francois Vreÿ, "Good Order at Sea off West Africa," in Towards Good Order at Sea: African Experiences, ed. Thomas Mandrup and Francois Vreÿ (South Africa: Sun Press, 2015), 183-206, p.190.

${ }^{19}$ Hans Langeveld and Simon Delany, "The Impact of Oil Exploration, Extraction and Transport on Mangrove Vegetation and Carbon Stocks in Nigeria," 2014, https://milieudefensie.nl/publicaties/rapporten/oil-industryimpact-nigeria, p.4.

${ }^{20}$ Barisere Rachel Könnet, "Inadequate Monitoring and Enforcement in the Nigerian Oil Industry: The Case of Shell and Ogoniland," Cornell International Law Journal 47, no. 1 (2014): 181-204, p.194; Tom Bawden, "Shell 'Uses Sabotage Claims to Avoid Blame for Nigeria Oil Spills,", Independent, 2013.

${ }^{21}$ Barisere Rachel Könnet, "Inadequate Monitoring and Enforcement in the Nigerian Oil Industry: The Case of Shell and Ogoniland," Cornell International Law Journal 47, no. 1 (2014): 181-204p.196.

${ }^{22}$ See Chioma Onuegbu, “Oil Spill: Mobil Hasn't Paid Any A’Ibom Community Compensation in 46 Years Chief Nduese Essien,” Vanguard Nigeria, 2017, https://www.vanguardngr.com/2017/08/oil-spill-mobil-hasnt-
} 
In an interview with Rev. Samuel Ayadi, the Coordinating Chairman of the Akwa-Ibom State and the Acting Chairman of the Niger Delta Branch ARFAN, he noted that the bad management and lack of respect for the environment by oil companies have robbed his members of the ability to provide for their families including not being able to send their children to school. According to him, the oil leakages which result in the pollution of the coastal environment are due to lack of management, as some of these pollutions are caused by rusty pipelines that are no longer fit for purpose. He also noted that the current system is ineffective in holding oil companies to account, which makes them less concerned about caring for the environment in which they work, compared to how the same oil companies operate in the developed countries - especially their countries of origin in the global Northwere they are held accountable for their actions. ${ }^{23}$ The lack of respect for the marine environment he adds, is evident also, in the way oil companies engage in haphazard clean-up exercises, or not at all, which in the long run, causes further harm to the marine environment. ${ }^{24}$ Espousing this view, Ndimele, Saba, Ojo, Ndimele, Anetekhai and Erondu argues that the degradation caused by oil spillages is worsened by the fact that the oil companies are often reluctant to clean up their spillages, even when they do, the methods used tends to cause more harm to the marine environment. ${ }^{25}$

The Bonga Oil Field Spillage by the Shell Nigeria Exploration and Production Company (SNEPCO) on the 20th December 2011 exemplifies his claims. The spill which was caused by equipment failure resulted in the discharge of an estimated 40,000 barrels of crude oil into the Atlantic Ocean - with more than 168, 000 people from 350 communities in the Niger Delta area affected. ${ }^{26}$ As well as the immediate damage caused to the marine environment - the pollution of the mangrove where 60 per cent of the fish in the Gulf of Guinea breed ${ }^{27}$ - by the spillage, which covered 185 kilometres along the Nigeria coast, disrupted the source of livelihood of an estimated 28,000 fishermen operating in the region. ${ }^{28}$

Beyond the immediate environmental damage caused by the spillage, Rev. Ayadi noted that it resulted in the suspension of fishing activities for his members for nine months to allow for the cleanup exercise. This period was extremely difficult for many of the fisher folks and their families as they

paid-aibom-community-compensation-46-years-chief-nduese-essien/; P. Steyn, “Oil, Ethnic Minority Groups and Environmental Struggles against Multinational Oil Companies and the Federal Government in the Nigerian Niger Delta State since the 1990s," in A History of Environmentalism: Local Struggles, Global Histories, ed. Lise Sedrez Marco Armiero (London.New Delhi.New York.Sydney: Bloomsbury, 2014), 57-82.

${ }^{23}$ Interview with Rev. Ayadi, (2017). Coordinating Chairman Akwa-Ibom State and the Acting Chairman Niger Delta Branch of ARFAN. Telephone interview, June 28th.

${ }^{24}$ Ibid.

25 P.E. Ndimele et al., "Remediation of Crude Oil Spillage," in The Political Ecology of Oil and Gas Activities in the Nigerian Aquatic Ecosystem, ed. P.E. Ndimele (United Kingdom: Elsevier Academic Press, 2018), 36786.

${ }^{26}$ Arodiegwu Eziukwu, "Bonga Oil Spill Affected 168,000 People in 350 Communities - Monarch," Premium Times, 2015, https://www.premiumtimesng.com/regional/south-south-regional/180674-bonga-oil-spill-affected168000-people-in-350-communities-monarch.html.

${ }^{27}$ André Standing, "Corruption and Industrial Fishing in Africa," U4 Brief, vol. 7 (Cape Town, 2008), https://www.cmi.no/publications/file/3188-corruption-andindustrial-fishing-in-africa.pdf.

${ }^{28}$ Arodiegwu Eziukwu, "Bonga Oil Spill Affected 168,000 People in 350 Communities — Monarch." 
did not have an alternative source of livelihood, nor were they compensated for their loss. ${ }^{29}$ Rev. Ayadi also noted that the Bonga fish, which the facility is named after and which were commonly caught in the area, are now difficult to catch, due to the Bonga oil spill and the subsequent environmentally unfriendly clean-up exercise that followed. According to him:

There is hunger in the fishing communities, there is no fuel subsidy from the government, our effort to survive is threatened by pollution. Fishing is the only thing we know. The Bonga fish that is common in our region throughout the year is now impossible to catch due to the oil spillage. Rather than execute an effective clean-up, the company used chemicals to sink the oil, which leads to further damage to the surviving species. As I speak to you, we don't even see Bonga fish to catch as much as we used to, which is why some fishermen are turning to crayfish. ${ }^{30}$

Whether or not his claim can be substantiated, what is evident is that pollution from the operations of multinational oil companies has a devastating impact on the food security of the people whose source of livelihood is predominantly from the sea. ${ }^{31}$ The outcome is not only the immediate pollution of the marine environment, but, for the families affected, the spillage results in the lack of income leading to poverty, hunger, ill health and the ceasing of education for their children. ${ }^{32}$ This is damaging to the achievement of the United Nations Sustainable Development Goals (SDGs) such as SDG 14 which seeks to ensure the sustainable use of the sea, marine and ocean resources, whose attainment is already threatened by IUU fishing by commercial/foreign vessels. ${ }^{33}$

In a region with limited employment opportunities, one cannot ignore the potential impact food insecurity might have on the overall security of the region as those affected seek an alternative source of livelihood. ${ }^{34}$ There is nowhere that this is more accurate than in the Niger Delta region, as the actions of multinational oil companies have contributed to environmental degradation and untold hardship in

\footnotetext{
${ }^{29}$ Interview with Rev. Ayadi, (2017). Coordinating Chairman Akwa-Ibom State and the Acting Chairman Niger Delta Branch of ARFAN. Telephone interview, June 28th.

${ }^{30}$ Ibid.

${ }^{31}$ Okafor-Yarwood, "Nigeria's Depleting Fish Stocks May Pose a Threat to Regional Security"; Julius Osahon, "Oil Exploration Threatening 6.5 Million Fishing Population in Niger Delta"," The Guardian Nigeria, 2018, https://guardian.ng/news/oil-exploration-threatening-6-5-million-fishing-population-in-niger-delta-2/.

${ }^{32}$ See Arodiegwu Eziukwu, "Bonga Oil Spill Affected 168,000 People in 350 Communities - Monarch"; Owen Akenzua, "Oil Spill Victims Sue Shell in UK over Alleged \$3.6b Compensation," The Guardian Nigeria, 2017, https://guardian.ng/news/oil-spill-victims-sue-shell-in-uk-over-alleged-3-6b-compensation/; Adeyemo, Ubiogoro, and Adedeji, "Oil Exploitation, Fisheries Resources and Sustainable Livelihood in the Niger Delta, Nigeria."

${ }^{33}$ Also affected: SDG 1 seeks to see an end to poverty, SDG 2, seeks to have a world without hunger, SDG 3 , seeks to ensure good health, SDG 4, seeks to promote education and SDG 8 seeks to promote economic growth. See Okafor-Yarwood, "Illegal, Unreported and Unregulated Fishing, and the Complexities of the Sustainable Development Goals (SDGs) for Countries in the Gulf of Guinea.", p. 420.

${ }^{34}$ F.C Onuoha, "Piracy and Maritime Security in the Gulf of Guinea : Nigeria as a Microcosm" (Qatar, 2012); Michael Baghebo, Ubi Peter Samuel, and N. Nwagbara Eucharia, "Environmental Damage Caused by the Activities of Multiinational Oil Giants in the Niger Delta Region of Nigeria," Journal of Humanities and Social Science 5, no. 6 (2012): 9-13.
} 
the affected communities, especially for women. ${ }^{35}$ Some of these women tend to diversity their livelihood activities by engaging in trading business, especially when their husbands or partners have left in search of alternative income following the pollution of their farmlands and fishing grounds. ${ }^{36}$ For others, alternative source of livelihood includes 'taking advantage of the cash inducement of oil workers and others in the oil economy ${ }^{37}$ by engaging in prostitution. Suffice to say that the membership of the once active militant groups in the Niger Delta is comprised of former farmers and fishermen who have lost their sources of income to pollution attributed to the oil companies. ${ }^{38}$

The increased potential for transborder conflict, as fisher folks travel beyond their usual fishing grounds in search for fish, is also worth mentioning. During the interview with Rev. Ayadi, he noted that it is common practice for the Cameroonian 'gendarme' (police) to intimidate fisher folks from Nigeria by extorting money from them or confiscating their fishing equipment. ${ }^{39}$ It came as a shock, nevertheless, when, in July 2017, it was reported that the same police killed 97 Nigerian fisher folks following a dispute over an alleged levy. ${ }^{40}$ Although this claim is contested by the Cameroonian government, the Nigerian government have accused Cameroon of breaching an agreement to protect its citizens. ${ }^{41}$

Given the migratory/transboundary nature of fish and the fact that an estimated 60 per cent of the fisheries species in the Gulf of Guinea breed in the mangrove of Niger Delta, ${ }^{42}$ the continued pollution of the marine environment in the Niger Delta is likely to undermine the fish food security of littoral communities in other countries in the Gulf of Guinea. ${ }^{43}$ This will also have financial implications for countries in the region, especially where some of the species are already on the overexploited list, as depleting stock means less resource to attract investors from distant water fishing nations. ${ }^{44}$

\footnotetext{
${ }^{35}$ Ndimele et al., "Remediation of Crude Oil Spillage."

${ }^{36}$ E.B. Inyang and E.E. Udong, "Livelihood Insecurity and Diversification among Women in an Environmentally-Challenged Niger Delta Region, Nigeria," The International Journal of Humanities \& Social Studies 1, no. 1 (2013): 35-43.

${ }^{37}$ Edlyne Ezenongaya Anugwom and Kenechukwu N. Anugwom, "The Other Side of Civil Society Story: Women, Oil and the Niger Delta Environmental Struggle in Nigeria," GeoJournal 74, no. 4 (2009): 333-46, https://doi.org/10.1007/s10708-008-9239-4, p.342.

${ }^{38}$ I. Okafor-Yarwood, "Pollution, Fisheries and Food (in)Security in the Gulf of Guinea," TLI Think, 2018, https://papers.ssrn.com/sol3/papers.cfm?abstract_id=3117284, p.8.

${ }^{39}$ Interview with Rev. Ayadi, (2017). Coordinating Chairman Akwa-Ibom State and the Acting Chairman Niger Delta Branch of ARFAN. Telephone interview, June 28th.

${ }^{40}$ Okafor-Yarwood, "Nigeria's Depleting Fish Stocks May Pose a Threat to Regional Security."

${ }^{41}$ Okafor-Yarwood, "Pollution, Fisheries and Food (in)Security in the Gulf of Guinea.", p.8.

${ }^{42}$ Standing, "Corruption and Industrial Fishing in Africa."

${ }^{43}$ See Beth Polidoro et al., "Red List of Marine Bony Fishes of the Eastern Central Atlantic" (Switzerland, 2016); Tony J. Pitcher and William W L Cheung, "Fisheries: Hope or Despair?," Marine Pollution Bulletin 74, no. 2 (2013): 506-16, https://doi.org/10.1016/j.marpolbul.2013.05.045, p.510 \& 514.

${ }^{44}$ Alfonso Daniels et al., "Western Africa's Missing Fish; the Impacts of Illegal, Unreported and Unregulated Fishing and under-Reporting Catches by Foreign Fleets," 2016, https://www.odi.org/sites/odi.org.uk/files/resource-documents/10665.pdf; Etim, Belhabib, and Daniel Pauly, "An Overview of the Nigerian Marine Fisheries and a Re-Evaluation of Its Catch Data for the Years 1950 to 2010."
} 
Finally, whilst it is important to highlight the role of multinational oil companies in undermining the marine environment and thus threatening the long-term food security of littoral communities, it is impossible to ignore the role bad governance has played in contributing to the neglect of the marine environment. This is especially evident when one takes into account that these same oil companies tend to operate in a different manner and uphold existing environmental regulations in their home countries and/or when operating in developed countries. ${ }^{45}$ To this end, the ensuing section looks at existing environmental regulations in Nigeria and their limitations.

\section{Environmental regulations and their shortcomings}

The Niger Delta region has strategic value to Nigeria due the abundance of energy resources within its boundaries. The crude oil derived from the region accounts for 95 per cent of Nigeria's foreign exchange earnings, and 80 per cent of the total revenue accruable to the Federal account. ${ }^{46}$ The gross domestic product (GDP) contribution from oil in 2017 was 8.68 per cent, rising to 9.61 per cent in the first quarter of 2018 which generates the bulk of the government's revenue. ${ }^{47}$ Also, abundant in the region are the once arable land, forests, rivers and mangroves teeming with fisheries and aquaculture resources. ${ }^{48}$ Yet, the former richness of the region is no longer reflected in the day to day reality of the people living in it, many of whom are either fisher folks or farmers. This is ultimately due to poor governance, ${ }^{49}$ which has resulted in environmental degradation — pollution of the farmlands and water sources - by the multinational oil companies operating in the region, thereby undermining the sources of livelihood of families and communities. ${ }^{50}$

\footnotetext{
${ }^{45}$ See Amaize, "Pollution Forces N-Delta Fishermen, Farmers to Abandon Occupation"; John Vidal, "Nigeria's Agony Dwarfs the Gulf Oil Spill. The US and Europe Ignore It," The Guardian, 2010; Peter Roderick, "Gas Flaring in Nigeria: A Human Rights, Environmental and Economic Monstrocity" (Amsterdam, 2005), https://doi.org/http://dx.doi.org/10.1016/j.pan.2012.11.029.

${ }^{46}$ Donald O. Omagu, "Oil Multinationals: Environmental Genocide and Socioeconomic Development in Nigeria's Niger Delta," in Environment and Economics in Nigeria, ed. Toyin Falola and Adam Paddock (New York \& London: Routledge, 2012), 107-24; E K Agbaeze, S N Udeh, and I O Onwuka, "Resolving Nigeria's Dependency on Oil - The Derivation Model," Journal of African Studies and Development 7, no. 1 (2015): 114, https://doi.org/10.5897/JASD2014.0303.

47 NBS, "Nigerian Gross Domestic Product Report Q4 \& Full Year 2017" (Abuja, 2018), http://www.nigerianstat.gov.ng/nanapages/download/329; NBS, "Nigeria Gross Domestic Product Report Q1 2018" (Abuja, 2018); Solape Renner, "Nigeria First-Quarter GDP Growth Slows Even as Oil Output Rises," Bloomberg, 2018, https://www.bloomberg.com/news/articles/2018-05-21/nigerian-economy-expands-in-firstquarter-as-oil-output-rises.

${ }^{48}$ Samuel Inyang, "South-South: The Anatomy of a People, Resources," NBF, 2009, http://www.nigerianbestforum.com/generaltopics/south-south-the-anatomy-of-a-people-resources/.

${ }^{49}$ Emmanuel M. Akpabio and Nseabasi S. Akpan, "Governance and Oil Politics in Nigeria's Niger Delta: The Question of Distributive Equity," Journal of Human Ecology 30, no. 2 (2010): 111-21, https://doi.org/10.1080/09709274.2010.11906280.

${ }^{50}$ B.O. Nwankwo, "The Politics of Conflict over Oil in the Niger Delta Region of Nigeria: A Review of the Corporate Social Responsibility Strategies of the Oil Companies," American Journal of Educational Research 3, no. 4 (2015): 383-92, https://doi.org/10.12691/education-3-4-1; Amnesty International, "Nigeria: Petroleum, Pollution and Poverty in the Niger Delta" (London, 2009),
} 
The multinational oil companies operating in Nigeria have to take responsibility for their own laxity, evident in decades of poor maintenance and underinvestment, which have resulted in the corrosion of ageing facilities and the subsequent equipment failure and oil spillages ${ }^{51}$ Similarly, the Nigerian state may be criticised for not having a robust system for regulating the activities of these companies and holding them responsible for their actions. The first oil exploration in the Niger Delta occurred in 1956; however, it was not until 1992 (36 years later) that the first ever environment impact assessment was undertaken. ${ }^{52}$ The first ever statute aimed exclusively at addressing environmental issues was enacted in 1988 under Decree 58 of the same year - the Federal Environmental Protection Agency Act. The amended ACT No. 59 of 1992 saw the establishment of FEPA—now Ministry of Environment—which is responsible for instituting natural environmental standards. ${ }^{53}$ However, since it was established, FEPA has not implemented any legal sanctions or compelled any of the multinational oil companies operating in the country to pay compensation or restore the polluted environment to an acceptable level. Hence it is deemed to be ineffective. ${ }^{54}$ The lack of and/or weak enforcement of FEPA resulted in low compliance by the oil companies and subsequently lead to its repeal and replacement by the Federal Government of Nigeria in $2007 .^{55}$

Beyond FEPA, other regulators have been introduced, but they too have not yet brought about any significant changes. The National Oil Spill Detection and Response Agency (NOSDRA) was established in 2006 for the purpose of implementing the National Oil Spill Contingency Plan

http://search.ebscohost.com/login.aspx?direct=true \&db=a9h\&AN=15491079\&site=ehost-live; Joseph C Ebegbulem, Dickson Ekpe, and Theophilus Oyime Adejumo, "Oil Exploration and Poverty in the Niger Delta Region of Nigeria: A Critical Analysis," International Journal of Business and Social Science 4, no. 3 (2013): $279-87$.

${ }^{51}$ O.O. Emoyan, I.A. Akpoborie, and E.E. Akporhonor, "The Oil and Gas Industry and the Niger Delta: Implications for the Environment," Journal of Applied Environmental Management 12, no. 3 (2008): 11831184a29-37, https://doi.org/10.1007/BF00730279; Amnesty International, "Negligence in the Niger Delta: Decoding SHELL and ENI's Poor Record on Oil Spills" (London, 2018), https://www.amnesty.ch/de/themen/wirtschaft-und-menschenrechte/fallbeispiele/nigeria/dok/2018/nigeriafahrlaessigkeit-von-shell-eni/negligence-in-the-niger-delta.pdf; C.H. Achebe, U.C. Nneke, and O.E. Anisiji, "Analysis of Oil Pipeline Failures in the Oil and Gas Industries in the Niger Delta Area of Nigeria," Proceeding of International MultiConference of Engineers and Computer Scientiest II (2012): 1274-79, https://doi.org/10.3982/ECTA6706.

${ }^{52}$ Omagu, "Oil Multinationals: Environmental Genocide and Socioeconomic Development in Nigeria's Niger Delta.", p. 107 \& 112.

${ }^{53}$ S. I. Omofonmwan and G. I Osa-Edoh, "The Challenges of Environmental Problems in Nigeria," Journal of Human Ecology 23, no. 1 (2008): 53-57, https://doi.org/10.1080/09709274.2008.11906054, p.56.

${ }^{54}$ Donald O. Omagu, "Oil Multinationals: Environmental Genocide and Socioeconomic Development in Nigeria's Niger Delta," in Environment and Economics in Nigeria, ed. Toyin Falola and Adam Paddock (New York \& London: Routledge, 2012), 107-24, p. 112; Aniefiok E. Ite et al., "Petroleum Exploration and Production: Past and Present Environmental Issues in the Nigeria's Niger Delta," American Journal of Environmental Protection 1, no. 4 (2013): 78-90, https://doi.org/10.12691/env-1-4-2.

${ }^{55}$ Muhammed Tawfiq Ladan, "Review of NESREA Act 2007 and Regulations 2009-2011: A New Dawn in Environmental Compliance and Enforcement in Nigeria," Law, Environment and Development Journal 8, no. 1 (2012): 118-37, p.119. 
(NOSCP). ${ }^{56}$ The institution of the contingency plan and the agency that followed are in compliance with the International Convention on Oil Pollution Preparedness, Response and Cooperation (OPRC 90), ${ }^{57}$ to which Nigeria is a signatory. Specifically, Article 1 (1) of OPRC stipulates that member states should take appropriate measures to prepare for and respond to an oil pollution incident. ${ }^{58}$ However, as with the limitations of other existing regulations, executing their role and enforcing the provisions of NOSCP have been difficult due to what the Director-General of NOSDRA describes as inadequate funds, manpower, equipment and a weak legal framework...'. ${ }^{59}$ These inadequacies have hindered their ability to effectively execute their mandate.

The National Environmental Standards and Regulation Enforcement Agency (NESREA) Establishment Act 2007-replacing Federal Environmental Protection Act—which is responsible for environmental protection, biodiversity conservation, and sustainable exploitation of natural resources in the country. ${ }^{60}$ In addressing the subject of spillages and/or the deposit of harmful materials in the environment, section 27(1) notes:

The discharge in such harmful quantities of any hazardous substance into the air or upon the land and the waters of Nigeria or at the adjoining shorelines is prohibited, except where such discharge is permitted or authorized under any law in force in Nigeria. ${ }^{61}$

However, the prohibition of the discharge of hazardous substances in 'harmful quantities' by the NESREA Act, according to Oshionebo, undermines the Act itself. According to him, by prohibiting the discharge of hazardous wastes in 'harmful quantities', the Act infers that 'unharmful quantities' of such substances can be discharged. ${ }^{62}$ Whilst there is an established limit on the discharge of effluents in Nigeria, ${ }^{63}$ Oshienobo and Cui argue that NESEAR does not have the capability to enforce this provision

\footnotetext{
${ }^{56}$ Peter C Nwilo and Olusegun T Badejo, "Impacts and Management of Oil Spill Pollution along the Nigerian Coastal Areas," 2005, https://www.fig.net/resources/publications/figpub/pub36/chapters/chapter_8.pdf.

${ }^{57}$ ILO, "International Convention on Oil Pollution Preparedness , Response and Co-Operation, 1990," 1990, https://www.ilo.org/dyn/natlex/docs/ELECTRONIC/93349/109093/F578688552/International Convention on Oil Pollution Prepare.pdf.

58 IMO, "International Convention on Oil Pollution Preparedness, Response and Cooperation, 1990, (with Annex and Procès- Verbal of Rectification). Concluded at London on 30 No Vember 1990,", (Entered into force 13 May 1995, accession by Nigeria, 25 May 1993) United Nations - Treaty Series, 1995, https://treaties.un.org/doc/publication/unts/volume 1891/volume-1891-i-32194-english.pdf.

${ }^{59}$ Egufe Yafugborhi, "No TitleaNigeria Lags behind in Response to Oil Spill —NOSDRA," Vanguard Nigeria, 2018, https://www.vanguardngr.com/2018/04/nigeria-lags-behind-response-oil-spill-nosdra/.

${ }^{60}$ NESREA, "National Environmental Standards and Regulations Enforcement Agency (Establishment) Act, 2007," NESREA, 2007, http://extwprlegs1.fao.org/docs/pdf/nig120569.pdf; Muhammed Tawfiq Ladan, "Review of NESREA Act 2007 and Regulations 2009-2011: A New Dawn in Environmental Compliance and Enforcement in Nigeria," Law, Environment and Development Journal 8, no. 1 (2012): 118-37, p.120.

${ }^{61}$ NESREA, "National Environmental Standards and Regulations Enforcement Agency (Establishment) Act, 2007." Provision/article....

${ }^{62}$ Evaristus Oshionebo, Regulating Transnational Corporations in Domestic and International Regimes: An African Case Study (Toronto: University of Toronto Press, 2009), p.57.

${ }^{63}$ Nigeria, "National Environmental Protection (Effluent Limitation) Regulations," Federal Environmental Protection Agency, 1991, http://extwprlegs1.fao.org/docs/pdf/nig120290.pdf.
} 
because the agency does not have the expertise and equipment to do so. ${ }^{64}$ Ekhator has compared the similarities between NOSDRA and NESREA and arrived at the conclusion that in an attempt to prevent a conflict of interest between the two agencies, the investigation of oil spills was removed from the ambit of NESREA. ${ }^{65}$ As a result, NOSDRA is 'statutorily required to prevent, control and respond to oil spill incidences in Nigeria'. ${ }^{66}$ NESREA however, despite 'its innovative provisions of mobile courts in environmental cases, has been criticised on the ground that it is narrowly focused in comparison with the now defunct FEPA Act'. ${ }^{67}$ Evidentially, the problem does not lie with the lack of legislation as there are many, but, rather, the lack of capacity to enforce them. Specifically, there are different underlying causes as to why existing regulations and efforts to implement them have failed, including, but not limited to a perceived lack of political will, corruption, ineffective implementation of regulations where they exist, the lack of enforcement when regulations are violated, the lack of institutional capacity of regulatory agencies and overambitious legislation or guidelines. ${ }^{68}$

The failure to implement existing regulations in their entirety can also be put down to conflict of interest, as the Federal Government is responsible for instituting and implementing the environmental regulations, yet they also own some of the oil companies being regulated. ${ }^{69}$ According to Cragg, HurstCroft and Samiama, 'if the regulators, or indeed the ministry, rely on the oil sector for revenue in any way..., ${ }^{70}$ there might be instances where they (in the Nigerian case, those charged with the responsibility of putting into effect the many environmental laws or guidelines) may be reluctant to enforce the stipulations of the regulations because enforcement will mean a reduction in their income. ${ }^{71}$

\footnotetext{
${ }^{64}$ Evaristus Oshionebo, Regulating Transnational Corporations in Domestic and International Regimes: An African Case Study (Toronto: University of Toronto Press, 2009),p.57; Roberto Cui, Oil Multinationals in Nigeria: Human Rights, Sustainable Development and the Law (Hamburg: Anchor Academic Publishing, 2015), p.50-51.

${ }^{65}$ Eghosa Osa Ekhator, "Environmental Protection in the Oil and Gas Industry in Nigeria: The Roles of Governmental Agencies.", p.199.

${ }^{66}$ Eghosa Osa Ekhator., p.199.

${ }^{67}$ D.K. Derri and S.E. Abila, "A Critical Examination of the National Enviromental Standards and Regulation Enforcement Agency (Establishment) Act 2007," in Law and Petroleum Industry in Nigeria: Current Challenges : Essays in Honour of Justice Kate Abiri, ed. Festus Emiri and Gowon Deinduomo (Lagos: Malthouse Press Limited, 2009), 1-10, p.10.

${ }^{68}$ Stakeholder Democracy, "Rumuekpe a Study in Disempowerment, Conflict, and Peacebuilding," Human Impact of Conflict Rumuekpe, 2015; Abiodun Odusote, "Nigeria : The Matrix Between Fragility of Livelihoods and Conflict," Journal of Global Initiatives: Policy, Pedagogy, Perspective 10, no. 2 (2016); UNEP,

"Environmental Assessment of Ogoniland"; Oludayo G Amokaye, "Environmental Pollution and Challenges of Environmental Governance in Nigeria," British Journal of Arts and Social Sciences 10, no. I (2012): 26-41; Hakeem Ijaiya and O T Joseph, "Rethinking Environmental Law Enforcement in Nigeria," Beijing Law Review 5, no. December (2014): 306-21, https://doi.org/10.4236/blr.2014.54029; Lisa Stevens, "The Illusion of Sustainable Development: How Nigeria's Environmental Laws Are Failing the Niger Delta," The Vermont Law Review 36 (2011): 388-407.

${ }^{69}$ Barisere Rachel Könnet, "Inadequate Monitoring and Enforcement in the Nigerian Oil Industry: The Case of Shell and Ogoniland," Cornell International Law Journal 47, no. 1 (2014): 181-204, p.195.

${ }^{70}$ C. Cragg, Hurst-Croft, and I. Samiama, "Pollution Control in the Global Oil Industry in Relation to Reform in Nigeria.", p.15.

${ }^{71}$ C. Cragg, Hurst-Croft, and I. Samiama., p.6.
} 
For instance, effecting the implementation of the environmental regulation in its entirety may require the suspension of oil production, to allow for the clean-up of contaminated lands and water sources. ${ }^{72}$ However, since the Federal government rely on the oil sector for a huge part of their revenue, it is not surprising that the agencies responsible for enforcing these regulations appear to be inadequately alert to the many violations of the regulations and sometimes are seen to turn a blind eye. Espousing this argument Ezike notes that the '...penalty for gas flaring remains a paltry sum of N10.00 (£0.0215)... for every cubic [foot] of gas flared', ${ }^{73}$ which makes one wonder whether there were any real intentions to put an end to gas flaring, which accounts for an estimated 85 per cent of the gas produced in Nigeria. ${ }^{74}$

The preceding argument is true for Nigeria, where the regulating authority is also aligned with the Ministry of Energy (Petroleum Resources). The possibility for a conflict of interest is evinced by the fact that it is within the remit of the Nigerian Department of Petroleum Resources (DPR) to supervise and regulate the oil and gas sector, as well as enforce environmental laws. Moreover, the DPR is formally part of the Ministry of Petroleum Resources (MPR) and the Nigerian National Petroleum Corporation (NNPC) and thus, is closely aligned with the Ministry of Energy, which is responsible for developing the country's energy resources, of which the oil and gas industry is an integral part. ${ }^{75}$ It follows that, the DPR, cannot independently enforce regulations regarding oil pollution due to these said conflicts of interest. ${ }^{76}$ Encapsulating this position, the World Bank notes,

...this situation has resulted in the Government inadequately regulating oil pollution while, at the same time, being party to [the cause of] much of the oil related environmental problems of the Niger Delta. ${ }^{77}$

There is also the issue of corruption, especially by the elites in the communities hosting the oil companies (Kings and village heads), which underscores the limitations of the spillage compensation policy when it is implemented. This practice, according to Adeyemo, is termed the 'benefit captor syndrome'. These are elites that supposedly represent and or receive compensation on behalf of their

\footnotetext{
${ }^{72}$ C. Cragg, Hurst-Croft, and I. Samiama.

${ }^{73}$ Chukwuemeka Chuks Ezike, "Environmental Crime Liability of the Nigerian Government in Its Oil Pollution Menace.," Environmental Risk Assessment and Remediation 02, no. 02 (2018), https://doi.org/10.4066/25298046.100035, p.2.

${ }^{74}$ Ibid.

${ }^{75}$ Könnet, "Inadequate Monitoring and Enforcement in the Nigerian Oil Industry: The Case of Shell and Ogoniland."

${ }^{76}$ Mark C. Thurber, Ifeyinwa M. Emelife, and Patrick R P Heller, "NNPC and Nigeria's Oil Patronage EcoSystem," in Oil and Governance: State-Owned Enterprises and the World Energy Supply, ed. David G. Victor, David R. Hults, and Mark C. Thurber (New York: Cambridge University Press, 2011), 701-52; Philip Ejoor Agbonifo, "Risk Management and Regulatory Failure in the Oil and Gas Industry in Nigeria: Reflections on the Impact of Environmental Degradation in the Niger Delta Region," Journal of Sustainable Development 9, no. 4 (2016): 1, https://doi.org/10.5539/jsd.v9n4p1.

77 The World Bank, "Defining an Environmental Development Strategy for the Niger Delta," World Bank, vol. 2 (Geneva, 1995), p.45.
} 
communities; however, this compensation is rarely in fact received by the communities. ${ }^{78}$ During a focused group discussion with fisher folks in Bonny Island, those present shared their experience of misappropriation of compensation money by the traditional ruling elites. According to them:

...community Chiefs especially, the King is as bad as the government. They spend the money given to the communities as compensation for pollution or as gifts from the oil companies on expensive cars and sending their children abroad. While the people were hungry and struggling to make ends meet, the King had a party some years ago to celebrate his first billion. ${ }^{79}$

Similar narratives abound across most communities in the Niger Delta, as traditional leaders often fail to redistribute funds to the relevant people, which has resulted in resentment and frustration, especially amongst the youth. ${ }^{80}$

The implementation of the existing regulations/guidelines are also hampered by a triad of problems - ineffective implementation of regulations where they exist, the lack of enforcement when those regulations are violated and the lack of institutional capacity of regulatory agencies. The latter issue, which strongly contributes to the second, has resulted in poor monitoring and complete reliance on the oil companies for data, thus allowing them to follow their own assessment. ${ }^{81}$ As a result, regulating agencies cannot corroborate the data provided by the oil companies, as they do not have the resources to do so. More precisely, NOSDRA is statutorily responsible for detecting and responding to oil spillages in Nigeria; however, a 2013 report by Amnesty International noted that the investigations for such spillages are usually spearheaded by oil companies' personnel and not by NOSDRA. The agency is thus seen to be dependent on the company involved in an oil spill incident, as the oil company provides the transport to the site of the spillages as well as technical expertise and data, all of which agencies such as NOSDRA and the DPR do not have. ${ }^{82}$ This also gives the oil companies the freedom to decide when the investigation starts. The historical failure to establish an independent regulator that is well equipped to enforce the regulations and guidelines, despite the efforts of previous governments to do so, is, according to Thurber, Emelife and Heller ' ...part of a lurching reform that does nothing to sustainably alter the functioning of the petroleum sector' ${ }^{83}$

\footnotetext{
${ }^{78}$ Ademola Morakinyo Adeyemo, "Environmental Policy Failure in Nigeria and the Tragedy of Underdevelopment of Niger Delta Region,” 2008, p.57.

${ }^{79}$ This was the views of the Fisher folks from one of the fishing settlements in Bonny, during a focus group discussion in December 2015.

${ }^{80}$ Stakeholder Democracy, "Rumuekpe a Study in Disempowerment, Conflict, and Peacebuilding.” P.57.

${ }^{81}$ UNEP, "Environmental Assessment of Ogoniland"; Könnet, "Inadequate Monitoring and Enforcement in the Nigerian Oil Industry: The Case of Shell and Ogoniland"; O.C. Eneh and V.C. Agbazue, "Protection of Nigeria's Environment: A Critical Policy Review," Journal of Environmental Science and Technology 4, no. 5 (2011): 490-97.

${ }^{82}$ Amnesty International, "Bad Information: Oil Spill Investigations in the Niger Delta" (London, 2013), www.amnesty.org/en/library/asset/AFR44/.../afr440282013en.pdf.

${ }^{83}$ Mark C. Thurber, Ifeyinwa M. Emelife, and Patrick R P Heller, "NNPC and Nigeria's Oil Patronage EcoSystem," in Oil and Governance: State-Owned Enterprises and the World Energy Supply, ed. David G. Victor, David R. Hults, and Mark C. Thurber (New York: Cambridge University Press, 2011), 701-52, p. 716.
} 
Finally, environmental regulations or guidelines have not always lead to any meaningful outcome for communities in the Niger Delta because they are overambitious and unrealistic, and thus falter very easily. ${ }^{84}$ This has made some of the stipulations of EGASPIN, which is within the auspices of the DPR, impossible to implement. ${ }^{85}$ Specifically, EGASPIN requires that, in cases of oil spills, actions must be taken within 24 hours of the spillage, which is impractical given that, in many instances, the oil companies might not be aware of such spillages until much later, which often is outside the 24 hours' time limit. ${ }^{86}$ Even when the oil companies are able to meet the 24 hours deadline as stipulated, as previously stated NOSDRA, which is the enforcement agency, does not have the capacity to enforce the regulations as they rely on the oil companies for transportation to spillage sites and data. The failures in the enforcement agencies are evident from the fact that six years since the Bonga Oil Field Spillage, communities and even the government have not been compensated, with SNEPCO refusing to pay a US\$3.6 billion fine despite a court ruling in June $2018,{ }^{87}$ for it to do so. ${ }^{88}$ Amongst other things, the Bonga Oil Field example not only shows the lack of respect by SNEPCO for the communities that have welcomed them, but also highlights the incapacity of the enforcement agencies to fully implement the responsibilities associated with their institutions. The Bonga Oil Field example is typical of how spillages are addressed in the Niger Delta. In Bonny Island for instance, which is home to the Nigerian Liquefied Natural Gas (NLNG), in cases of oil spillages fisher folks have been known to be prevented from fishing in the affected area for up to six months to allow for the clean-up of the spillages. According to the President of the Bonny Fishers Association:

... spillages spoil our nets, so we tend not to fish in a particular area for up to six months until such spillages are cleared, with little to no compensation for the accrued loss in earning. ${ }^{89}$

This has resulted in some of the affected fisher folks fishing further afield or looking for an alternative source of income to adapt to the impact of depleting fisheries.

\footnotetext{
${ }^{84}$ Lisa Stevens, "The Illusion of Sustainable Development: How Nigeria's Environmental Laws Are Failing the Niger Delta"; C. Cragg, Hurst-Croft, and I. Samiama, "Pollution Control in the Global Oil Industry in Relation to Reform in Nigeria"; Kingsley Edu, "A Review of the Existing Legal Regime on Exploitation of Oil and the Protection of the Environment in Nigeria," Commonwealth Law Bulletin 37, no. 2 (2011): 307-27, https://doi.org/10.1080/03050718.2011.572637; Amokaye, "Environmental Pollution and Challenges of Environmental Governance in Nigeria."

${ }^{85}$ As a regulatory tool the DPR issued the EGASPIN in 1991, this was later reviewed in 2002. See DPR, "Environmental Guidelines and Standards for the Petroleum Industry in Nigeria (EGASPIN), Issued by the Department of Petroleum Resources Lagos 1991," Revised Edition, 2002, http://www.ngfcp.gov.ng/media/1066/dprs-egaspin-2002-revised-edition.pdf.

${ }^{86}$ Ayobami Olaniyan, "The Law and Multi-Agency Response to Oil Spill Incidents in Nigeria," Interspil Amsterdam (Amsterdam, 2015).

87 G.U Ugwuoma, "Litigation Update: Court No.1," Advocaat Law Practice, 2018, http://www.advocaat-law.com/assets/resources/341e36a14b167a82e12df3ff9e6c4e3b.pdf.

${ }^{88}$ Chineme Okafor, "NOSDRA to Shell: Obey Court Order, Pay \$3.6bn Fine over Bonga Oil Spill," ThisDay Live, 2018, https://www.thisdaylive.com/index.php/2018/07/05/nosdra-to-shell-obey-court-order-pay-3-6bnfine-over-bonga-oil-spill/.

${ }^{89}$ Interview with Mr. Bristol, held in Bonny Island, December 2015.
} 


\section{Conclusion}

This paper has explored the role of pollution as one of the key factors that undermines the sustainable use of the marine environment, especially in the Niger Delta region. It has argued that pollution in the form of spillages by the multinational oil companies operating in the region has played a significant role in undermining the marine environment leading to the depletion of fisheries resources. This has had severe consequences on the food security of the littoral communities across the Niger Delta, as their main source of livelihood has been diminished. In reviewing the responsibility of the Nigerian government to ensure that the perpetrating companies are held accountable for their actions, the paper has found that, whereas the existing regulations sometimes do not go far enough, the main problem is that the enforcement agencies do not have the capacity to fulfil their mandate which perpetuates the downward spiral of environmental degradation affecting coastal communities.

To this end, this paper notes that it is impossible for a country like Nigeria to reverse the impact of years of neglect of their littoral environment unless the government takes firm action in holding the oil companies accountable for their pollution. The first step required is a comprehensive strengthening of some of the legal frameworks /guidelines on the environment - such as EGASPIN, by addressing some of the loopholes that have already been identified such as the unrealistic timeline for reporting and acting on oil spills. Coupled with that, for the legal frameworks to be effective, there is a need to ensure adequate support for the enforcement agencies in the form of investment in equipment and manpower that would allow them to carry out their duties to implement both existing and enhanced regulations with less dependence on the oil companies. There is also an urgent need for ensuring that affected communities are duly compensated, and clean-up exercises are carried out to the same level that is found in developed countries. Furthermore, effective implementation of the existing environmental regulations can only happen through enhancing the powers of regulating agencies and/or making them independent of the Ministry of Energy to allow for unbiased representation and implementation of said regulations. The review of the existing guidelines and regulations should also be swiftly followed by investment in infrastructure to be funded with fines generated from the infringement of laws.

Finally, the government must work to ensure that personnel are trained to be able to do their jobs effectively, as well as provide a better channel for the general public to get involved. These measures will make way for a stronger agency that will be committed to rooting out corrupt practices and fulfilling its primary responsibility, which is a commitment to a sustainable Nigerian environment. Failure to regulate and empower these institutions would see an increase in the negative cycle of the response to the perceived injustices in the Niger Delta, as the people affected by oil spillages continue to seek alternative sources of livelihood, including engaging in activities that threaten the security of the Nigerian state itself. Taking this much-needed action would go a long way in ensuring the sustainability of the marine resources, not only in Nigeria but across the Gulf of Guinea. 
